Jurnal Ilmiah Farmasi (Scientific Journal of Pharmacy 17(2) Agustus-Desember 2021, 127-136

ISSN: 1693-8666

available at http://journal.uii.ac.id/index.php/JIF

\title{
Correlation between potassium administration and resolution in patients with diabetic ketoacidosis
}

\section{Hubungan antara pemberian kalium dengan resolusi pada pasien ketoasidosis diabetik}

\author{
Rina Oktaviani ${ }^{1}$, Zullies Ikawati ${ }^{*}$, Nanang Munif Yasin ${ }^{2}$
}

${ }^{1}$ Magister Farmasi Klinik, Fakultas Farmasi, Universitas Gadjah Mada

2Departemen Farmakologi dan Farmasi Klinik Fakultas Farmasi Universitas Gajah Mada

*Corresponding author: zullies ikawati@ugm.ac.id

\begin{abstract}
Background: Diabetic ketoacidosis (DKA) is a life-threatening complication of acute diabetes mellitus (DM). Insulin is one of the therapies for DKA, which can reduce potassium levels by shifting potassium from extracellular to intracellular. Consequently, early administration of potassium is important in the resolution of DKA.

Objective: To determine the correlation between potassium administration and resolution in patients with DKA and the factors affecting such resolution.

Methods: An observational study was employed with a retrospective cohort design for inpatients with a diagnosis of DKA during the period of January 2015-August 2020 at Dr. Sardjito Hospital Yogyakarta. Appraisal of the resolution of DKA variable was based on the achievement of blood glucose targets, followed by 2 criteria of serum bicarbonate, $\mathrm{pH}$, and anion gap during 24 hours of therapy. This study involved 55 patients divided into groups with potassium administration and without potassium administration. Data were analyzed using the chi-square test and multivariate logistic regression.

Results: The resolution of DKA achieved in $\leq 24$ hours in the group with potassium was $48.5 \%$ (16 patients) while it was $18.2 \%$ (4 patients) without potassium. Based on the chi-square analysis, there was a relationship between potassium administration and the resolution of DKA $(\mathrm{p}=0.045 ; \mathrm{RR}=2.667 ; 95 \% \mathrm{CI}=1.028-6.920)$. The multivariate analysis showed that the severity and history of DM were positively related to the resolution of DKA ( $p=0.025$; OR: 8.901; 95\%CI=1.318-60.123 and $\mathrm{p}=0.017$; OR: 0.090; 95\%CI=0.012-0.652).

Conclusion: Potassium administration resulted in $48.5 \%$ of the DKA patients achieving a resolution in $\leq 24$ hours from the commencement of DKA therapy. The severity and history of DM became the factors that affected the resolution of DKA.
\end{abstract}

Keywords: diabetic ketoacidosis, potassium, resolution

\section{Intisari}

Latar belakang: Ketoasidosis diabetik (KAD) adalah komplikasi akut diabetes melitus (DM) yang mengancam jiwa. Insulin merupakan salah satu terapi KAD, yang dapat menurunkan kadar kalium dengan cara memindahkan kalium dari ekstraseluler ke intraseluler, sehingga pemberian awal terapi kalium berperan penting dalam resolusi KAD.

Tujuan: Mengetahui hubungan pemberian kalium dengan resolusi pada pasien KAD dan faktor yang mempengaruhi resolusi.

Metode: Penelitian observasional dengan rancangan kohort retrospektif pada pasien rawat inap dengan diagnosis KAD periode Januari 2015-Agustus 2020 di RSUP Dr. Sardjito Yogyakarta. Penilaian variabel resolusi KAD adalah ketercapaian target glukosa darah, diikuti 2 kriteria dari serum bikarbonat, pH, dan anion gap selama 24 jam terapi. Penelitian melibatkan 55 pasien yang terbagi ke dalam kelompok pemberian kalium dan tanpa pemberian kalium. Data dianalisis menggunakan uji chi-square dan multivariate logistic regression.

Hasil: Resolusi KAD yang dicapai selama $\leq 24$ jam pada kelompok dengan pemberian kalium sebesar $48,5 \%$ (16 pasien) dan 18,2\% (4 pasien) tanpa pemberian kalium. Berdasarkan analisis chi-square, terdapat hubungan antara pemberian kalium dengan resolusi $\operatorname{KAD}(\mathrm{p}=0,045 ; \mathrm{RR}=2,667 ; 95 \% \mathrm{CI}=1,028-6,920)$. Hasil analisis 
128 | Oktaviani, R., dkk. / Jurnal Ilmiah Farmasi (Scientific Journal of Pharmacy) 17(2) Agustus-Desember 2021, 127-137

multivariat menunjukkan derajat keparahan dan riwayat DM berhubungan positif terhadap resolusi KAD ( $\mathrm{p}=0,025 ; \mathrm{OR}=8,901 ; 95 \% \mathrm{CI}=1,318-60,123$ dan $\mathrm{p}=0,017 ; \mathrm{OR}=0,090 ; 95 \% \mathrm{CI}=0,012-0,652$ ).

Kesimpulan: Pemberian kalium menghasilkan 48,5\% pasien KAD yang mencapai resolusi $\leq 24$ jam dari awal terapi KAD dimulai. Derajat keparahan dan riwayat DM merupakan faktor yang mempengaruhi resolusi KAD.

Kata kunci: ketoasidosis diabetik, kalium, resolusi

\section{Pendahuluan}

Ketoasidosis diabetik didefinisikan sebagai suatu penyakit yang mengancam jiwa pada pasien diabetes, ditandai dengan ketonemia, hiperglikemia, dan asidemia (Dhatariya et al., 2013). Gangguan metabolisme ini disebabkan oleh defisiensi insulin dan peningkatan hormon regulasi (glukagon, katekolamin, kortisol, dan hormon pertumbuhan). Ketoasidosis diabetik umumnya terjadi pada pasien diabetes melitus tipe 1, namun tidak jarang ditemukan pada pasien diabetes melitus tipe 2 yang memiliki risiko stres katabolik, pembedahan, atau infeksi (Kitabchi et al., 2009).

Prevalensi kematian pasien ketoasidosis diabetik di negara maju adalah $<1 \%$, sedangkan kematian pada usia lanjut mencapai >5\% (Dhatariya et al., 2013; Kitabchi et al., 2009). Ketoasidosis diabetik dapat menyebabkan komplikasi jika tidak ditangani segera dengan terapi yang tepat. Komplikasi ketoasidosis diabetik yang umum terjadi berupa hipoglikemia, udema serebral, udema pulmonari, gagal ginjal akut, syok, dan gangguan elektrolit. Komplikasi yang jarang terjadi meliputi rabdomiolisis, stroke, penurunan fungsi kognitif, dan lain-lain (Westerberg, 2013). Tujuan utama terapi ketoasidosis diabetik adalah koreksi dehidrasi, penghentian produksi keton, penanganan hiperglikemia, koreksi cairan elektrolit, identifikasi faktor penyebab, serta melakukan kontrol rutin pada pasien (Alledregde et al., 2013).

Kadar kalium saat ketoasidosis diabetik dapat mengalami kondisi normal, peningkatan maupun penurunan. Variasi kadar kalium ini disebabkan oleh berbagai faktor di antaranya peningkatan tonisitas plasma, katabolisme protein, hiperglikemi serta penggunaan insulin. Penurunan kadar kalium dalam darah dapat dipicu oleh kondisi hiperglikemia dan ketonemia. Ke dua kondisi ini akan mendorong terjadinya diuresis osmotik sehingga pasien mengalami hipovolemia (Nyenwe \& Kitabchi, 2016). Selain itu, pemberian insulin yang merupakan terapi dari KAD akan mengaktifkan pompa $\mathrm{Na}^{+} / \mathrm{K}^{+}$-ATPase yang dapat berdampak pada peningkatan penyerapan kalium ke dalam sel dan pemburukan kondisi hipokalemia (Cieluch et al., 2018). Peningkatan kalium dapat terjadi karena adanya peningkatan tonisitas plasma maupun katabolisme protein yang mengakibatkan pergeseran kalium dan air dari ruang intraseluler menuju ruang ekstraseluler (Nyenwe \& Kitabchi, 2016).

Pemberian insulin berkelanjutan menyebabkan kadar kalium akan selalu turun selama perawatan KAD. Hal ini disebabkan karena insulin memindahkan kalium di ekstraseluler menuju ke intraseluler. Oleh karena itu, pemberian kalium penting dalam perawatan KAD untuk mencegah 
129 | Oktaviani, R., dkk. / Jurnal Ilmiah Farmasi (Scientific Journal of Pharmacy) 17(2) Agustus-Desember 2021, 127-137

komplikasi pada pasien, seperti aritmia (Cieluch et al., 2018). Pedoman penanganan KAD menyarankan penggantian kalium saat kadar serum kalium berada $<5,5 \mathrm{mEq} / \mathrm{L}$, hal ini bertujuan untuk mencegah terjadinya hipokalemia. Pada pasien dengan rentang kadar kalium 3,5 mEq/L-5,5 $\mathrm{mEq} / \mathrm{L}$ dilakukan pemberian terapi kalium dengan dosis $40 \mathrm{mmol} / \mathrm{l}$, sedangkan pada kadar kalium $<3,5 \mathrm{mEq} / \mathrm{L}$ pemberian dosis kalium perlu dikonsultasikan terlebih dahulu. Kadar kalium dipertahankan dalam rentang $4 \mathrm{mEq} / \mathrm{L}-5,5 \mathrm{mEq} / \mathrm{L}$ (Dhatariya et al., 2013). Pemantauan kadar kalium dilakukan setiap 2-6 jam selama perawatan KAD. Kalium yang umum digunakan dalam pencegahan hipokalemia dan koreksi kadar kalium pada perawatan KAD adalah premixed KCl (kalium klorida) (Dhatariya et al., 2013). $\mathrm{KCl}$ digunakan untuk menggantikan defisiensi $\mathrm{K}^{+}$dan penurunan $\mathrm{Cl}^{-}$(Nyenwe \& Kitabchi, 2016; Parsons et al., 2019).

Berdasarkan hal tersebut, pemberian kalium berperan penting dalam tercapainya resolusi pasien KAD. Resolusi ketoasidosis diabetik tercapai jika kadar gula darah $<200 \mathrm{mg} / \mathrm{dl}$ dan diikuti 2 kriteria dari serum bikarbonat $\geq 15 \mathrm{mEq} / \mathrm{L}, \mathrm{pH}$ darah $>7,3$, dan anion gap $\leq 12 \mathrm{mEq} / \mathrm{L}$ (Kitabchi et al., 2009). Resolusi KAD idealnya tercapai < 24 jam dari awal terapi diberikan. Apabila pasien KAD belum mengalami resolusi dalam waktu <24 jam, perlu dilakukan kajian terapi dan konsultasi pada dokter senior (Dhatariya et al., 2013).

Penelitian tentang kepatuhan penggantian kalium pada pasien ketoasidosis diabetik terhadap protokol, yang dilakukan oleh Cieluch et al (2018) menyatakan bahwa ketidakpatuhan penggantian kalium menyebabkan waktu perawatan KAD yang lebih lama. Berdasarkan hal tersebut, penelitian ini dilakukan dengan tujuan untuk menilai hubungan antara pemberian kalium dengan tercapainya resolusi pada pasien ketoasidosis diabetik selama $\leq 24$ jam dari awal terapi KAD diberikan. Penelitian ini juga bertujuan untuk mengidentifikasi faktor-faktor yang mempengaruhi resolusi ketoasidosis diabetik.

\section{Metode}

\subsection{Rancangan penelitian}

Penelitian ini merupakan penelitian yang bersifat observasional analitik dengan desain retrospektif kohort. Instrumen penelitian menggunakan catatan medik pasien dengan diagnosis ketoasidosis diabetik antara Januari 2015-Oktober 2020. Pengambilan data dilakukan di Instalasi Catatan Medik RSUP Dr. Sardjito secara consecutive sampling selama 1,5 bulan yaitu NovemberDesember 2020. 
130 | Oktaviani, R., dkk. / Jurnal Ilmiah Farmasi (Scientific Journal of Pharmacy) 17(2) Agustus-Desember 2021, 127-137

\subsection{Subyek penelitian}

Catatan medik yang memenuhi kriteria inklusi berupa catatan medik dari pasien dengan diagnosis KAD, usia >18 tahun, pasien yang memenuhi kriteria indikasi pemberian kalium selama $\leq 24$ jam, dan rekam medik yang lengkap. Kriteria eksklusi terdiri dari pasien meninggal $<24$ jam dari awal perawatan ketoasidosis diabetik dan pasien dengan komorbid gagal ginjal kronik. Sampel yang diperoleh yaitu 121 pasien dengan 55 pasien memenuhi kriteria inklusi. Subjek penelitian dibagi menjadi 2 kelompok, yaitu kelompok dengan pemberian kalium pada indikasi pertama pemberian dan kelompok tanpa pemberian kalium pada indikasi pertama pemberian.

\subsection{Tahap penelitian}

Penelitian ini telah disetujui oleh Medical and Health Research Ethic Committee Fakultas Kedokteran Universitas Gajah Mada, dengan nomor KE/FK/0925/EC/2020. Penelitian ini juga mendapatkan izin dari RSUP Dr. Sardjito Yogyakarta.

Data yang dikumpulkan berupa usia, jenis kelamin, indeks masa tubuh (IMT), penyakit penyerta, riwayat diabetes melitus, penggunaan obat lain (obat golongan steroid), dan kadar kalium admisi. Data laboratorium yang digunakan untuk menentukan derajat keparahan dan resolusi pasien antara lain kadar gula darah, pH, serum bikarbonat, dan anion gap. Data diolah untuk menilai pemberian kalium terhadap resolusi ketoasidosis diabetik.

\subsection{Analisis data}

\subsubsection{Penilaian pemberian kalium}

Pemberian kalium merupakan salah satu bagian penting dalam tercapainya resolusi ketoasidosis diabetik. Pemberian kalium diindikasikan pada pasien dengan kadar serum kalium <5,5 $\mathrm{mEq} / \mathrm{L}$ dan volume urin yang cukup. Pasien dengan kadar kalium $>5,5 \mathrm{mEq} / \mathrm{L}$ atau terdapat gelombang $\mathrm{T}$ yang lancip dan tinggi pada EKG (elektrokardiogram), pemberian kalium ditunda terlebih dahulu hingga kadar serum kalium $<5,5 \mathrm{mEq} / \mathrm{L}$ dan volume urin yang cukup. Pemberian kalium dilakukan segera setelah hasil kadar kalium menunjukkan nilai $<5,5 \mathrm{mEq} / \mathrm{L}$ dan sebelum pemeriksaan kadar kalium berikutnya dilakukan selama $\leq 24$ jam.

\subsubsection{Observasi resolusi ketoasidosis diabetik}

Resolusi ketoasidosis diabetik dinyatakan tercapai jika luaran klinik pasien terdapat nilai yang menunjukkan kadar gula darah $<200 \mathrm{mg} / \mathrm{dl}$ dan diikuti 2 kriteria dari serum bikarbonat $\geq 15$ $\mathrm{mEq} / \mathrm{L}$, $\mathrm{pH}$ darah $>7,3$, dan anion gap $\leq 12 \mathrm{mEq} / \mathrm{L}$ selama pengamatan $\leq 24 \mathrm{jam}$. Resolusi dikatakan tidak tercapai ketika nilai kriteria resolusi tidak tercapai selama waktu $\leq 24$ jam dari awal terapi ketoasidosis diabetik diberikan. 
131 | Oktaviani, R., dkk. / Jurnal Ilmiah Farmasi (Scientific Journal of Pharmacy) 17(2) Agustus-Desember 2021, 127-137

\subsubsection{Analisis statistik}

Analisis data deskriptif digunakan untuk menggambarkan karakteristik dasar pasien yang disajikan dalam bentuk persentase. Analisis data bivariat dilakukan untuk mengetahui hubungan antara pemberian kalium pada pasien KAD (variabel bebas) dengan resolusi KAD (variabel tergantung), menggunakan uji Chi-square atau uji Fisher's Exact dengan tingkat kepercayaan 95\% ( $\alpha$ $=0,05)$.

Analisis data multivariat bertahap menggunakan regresi logistik berganda dilakukan dengan tujuan untuk mengetahui hubungan antara variabel pengganggu dengan resolusi KAD. Variabel pengganggu meliputi usia, jenis kelamin, IMT, derajat keparahan, kadar kalium admisi, penyakit penyerta (infeksi, gangguan ginjal akut, kardiovaskular), riwayat penyakit diabetes melitus dan penggunaan obat lain (obat golongan steroid).

\section{Hasil dan pembahasan}

Berdasarkan penelaahan data rekam medis pada Januari 2015-Oktober 2020, dari total 120 pasien dengan diagnosis KAD, sebanyak 55 pasien memenuhi kriteria inklusi. Sebanyak 66 pasien dieksklusi di antaranya, 42 pasien dengan data tidak lengkap, 14 pasien dengan gagal ginjal kronis, dan 9 pasien meninggal dalam waktu $<24$ jam. Total dari 55 pasien tersebut dibagi ke dalam 2 kelompok, yakni kelompok pasien dengan pemberian kalium pada indikasi pertama pemberian sebanyak 33 pasien (60\%) dan kelompok tanpa pemberian kalium pada indikasi pertama pemberian sebanyak 22 pasien (40\%).

Data karakteristik pasien dari 2 kelompok tersaji pada Tabel 1. Karateristik kadar kalium admisi (hipokalemia, normokalemia, dan hiperkalemia) menunjukkan bahwa persebaran data ke dua kelompok tidak merata $(\mathrm{p}=0,000)$. Berdasarkan hasil analisis bivariat dengan chi-square (Tabel 2), diketahui terdapat hubungan antara pemberian kalium dengan resolusi $\operatorname{KAD}(p=0,045 ; R R=2,667$; $95 \% \mathrm{CI}=1,028-6,920)$. Persentase ketercapaian resolusi pada kelompok dengan pemberian kalium saat indikasi pertama pemberian sebanyak 16 pasien $(48,5 \%)$, sementara 17 pasien $(51,5 \%)$ tidak mencapai resolusi selama waktu $\leq 24$ jam. Ketercapaian resolusi $\leq 24$ jam pada kelompok tanpa pemberian kalium saat indikasi pertama pemberian sebanyak 4 pasien $(18,2 \%)$, dan yang tidak mencapai resolusi sebanyak 18 pasien $(81,8 \%)$.

Hasil analisis multivariat bertahap dapat dilihat pada Tabel 3. Berdasarkan hasil tersebut, parameter derajat keparahan $(\mathrm{p}=0,025 ; \mathrm{OR}=8,901 ; 95 \% \mathrm{CI}=1,318-60,123)$ dan riwayat diabetes melitus ( $\mathrm{p}=0,017 ; \quad \mathrm{OR}=0,090 ; 95 \% \mathrm{CI}=0,012-0,652)$ mempengaruhi ketercapaian resolusi 
132 | Oktaviani, R., dkk. / Jurnal Ilmiah Farmasi (Scientific Journal of Pharmacy) 17(2) Agustus-Desember 2021, 127-137

ketoasidosis diabetik. Hubungan negatif terhadap resolusi ketoasidosis diabetik selama $\leq 24$ jam ditemukan pada IMT, kadar serum kalium admisi, dan pasien KAD dengan komorbid kardiovaskular.

Tabel 1. Karakteristik pasien ketoasidosis diabetik

\begin{tabular}{|c|c|c|c|}
\hline Karakteristik Pasien & $\begin{array}{c}\text { Kelompok dengan } \\
\text { Pemberian Kalium } \\
(\mathrm{n}=33)\end{array}$ & $\begin{array}{c}\text { Kelompok tanpa } \\
\text { Pemberian Kalium } \\
(n=22)\end{array}$ & Nilai p \\
\hline \multicolumn{4}{|l|}{ Usia, n (\%) } \\
\hline 19-44 tahun & $16(48,5)$ & $12(54,5)$ & \multirow{2}{*}{0,869} \\
\hline$>44$ tahun & $17(51,5)$ & $10(45,5)$ & \\
\hline \multicolumn{4}{|l|}{ Jenis kelamin, $\mathrm{n}(\%)$} \\
\hline Laki-laki & $14(42,4)$ & $6(27,3)$ & \multirow{2}{*}{0,391} \\
\hline Perempuan & $19(57,6)$ & $16(72,7)$ & \\
\hline \multicolumn{4}{|l|}{ IMT, n (\%) } \\
\hline Normal & $21(63,6)$ & $16(72,7)$ & \multirow{2}{*}{0,681} \\
\hline Tidak normal & $12(36,4)$ & $6(27,3)$ & \\
\hline \multicolumn{4}{|l|}{ Keparahan, n (\%) } \\
\hline Ringan-sedang & $22(66,7)$ & $13(59,1)$ & \multirow{2}{*}{0,775} \\
\hline Berat & $11(33,3)$ & $9(40,9)$ & \\
\hline \multicolumn{4}{|l|}{ Kadar kalium admisi, n (\%) } \\
\hline Hipokalemia & $9(27,3)$ & $2(9,1)$ & \multirow{3}{*}{$0,000^{*}$} \\
\hline Normokalemia & $21(63,6)$ & $6(27,3)$ & \\
\hline Hiperkalemia & $3(9,1)$ & $14(63,3)$ & \\
\hline \multicolumn{4}{|l|}{ Komorbid, n (\%) } \\
\hline Infeksi & $26(78,8)$ & $20(90,9)$ & 0,413 \\
\hline Gangguan ginjal akut & $10(30,3)$ & $12(54,5)$ & 0,129 \\
\hline Kardiovaskular & $12(36,4)$ & $8(36,4)$ & 1,000 \\
\hline \multicolumn{4}{|l|}{ Riwayat DM, n (\%) } \\
\hline Riwayat DM & $26(78,8)$ & $14(63,6)$ & \multirow{2}{*}{0,354} \\
\hline Tidak Riwayat DM & $7(21,2)$ & $8(36,4)$ & \\
\hline \multicolumn{4}{|c|}{ Penggunaan obat steroid, n (\%) } \\
\hline Penggunaan steroid & $3(9,1)$ & $2(9,1)$ & \multirow{2}{*}{1,000} \\
\hline Tidak menggunakan steroid & $30(90,9)$ & $20(90,9)$ & \\
\hline
\end{tabular}

Keterangan: DM: Diabetes Melitus, IMT = Indeks Masa Tubuh

* uji Chi-square, tingkat kepercayaan 95\% (signifikansi $p$-value $<0,05$ )

Tabel 2. Hubungan antara pemberian kalium dengan resolusi KAD

\begin{tabular}{lccccc}
\hline Parameter & $\begin{array}{c}\text { Kelompok dengan } \\
\text { pemberian kalium } \\
(\mathbf{n = 3 3 )}\end{array}$ & $\begin{array}{c}\text { Kelompok tanpa } \\
\text { pemberian kalium } \\
(\mathbf{n = 2 2})\end{array}$ & Nilai p & RR & $\mathbf{9 5 \%}$ CI \\
\hline $\begin{array}{l}\text { Resolusi } \\
\text { n (\%) }\end{array}$ & $16(48,5)$ & $4(18,2)$ & & & \\
$\begin{array}{l}\text { Tidak resolusi } n \\
(\%)\end{array}$ & $17(51,5)$ & $18(81,8)$ & 0,045 & 2,667 & $1,028-6,920$ \\
\hline
\end{tabular}

Keterangan

*Hasil Uji Chi-square, tingkat kepercayaan 95\% (sigifikansi $p$-value $<0,05$ ) 
133 | Oktaviani, R., dkk. / Jurnal Ilmiah Farmasi (Scientific Journal of Pharmacy) 17(2) Agustus-Desember 2021, 127-137

Tabel 3. Analisis regresi logistik multivariat

\begin{tabular}{lccc}
\hline \multicolumn{1}{c}{ Parameter } & \multicolumn{3}{c}{ Analisis Regresi Multivariat } \\
& Nilai p & OR & 95\% CI \\
\hline Pemberian kalium & 0,083 & 4,683 & $0,817-26,847$ \\
IMT & 0,162 & 3,322 & $0,618-17,843$ \\
Kadar kalium admisi & 0,531 & 1,499 & $0,422-5,326$ \\
Keparahan & $0,025^{*}$ & 8,901 & $1,318-60,123$ \\
Komorbid Kardiovaskular & 0,244 & 0,393 & $0,82-1,893$ \\
Riwayat DM & $0,017^{*}$ & 0,090 & $0,012-0,652$ \\
\hline
\end{tabular}

Keterangan: DM: Diabetes Melitus, IMT= Indeks Masa Tubuh

*Uji multivariate logistic regression, tingkat kepercayaan 95\% (Signifikansi $<0,05$ )

Ketoasidosis merupakan kondisi darurat yang memiliki angka mordibitas dan mortalitas yang tinggi pada pasien diabetes melitus. Terapi yang tepat menjadi kunci utama dalam ketercapaian resolusi KAD, salah satunya pemberian kalium (Dhatariya et al., 2013). Sepengetahuan peneliti, penelitian ini merupakan penelitian pertama untuk mengetahui hubungan antara pemberian kalium dengan ketercapaian resolusi ketoasidosis diabetik selama waktu $\leq 24$ jam, sedangkan penelitian sebelumnya membahas tentang dampak kepatuhan penggantian terapi kalium terhadap waktu perawatan KAD. Penelitian ini menunjukkan bahwa pemberian kalium dapat mempercepat tercapainya resolusi ketoasidosis diabetik dalam waktu $\leq 24$ jam.

Karakteristik kadar kalium admisi menunjukkan perbedaan yang signifikan pada ke dua kelompok. Perbedaan tersebut dapat disebabkan oleh respon tubuh terhadap kondisi KAD yang berbeda sehingga terjadi variasi kadar kalium pada pasien. Kondisi KAD yang menyebabkan gangguan elektrolit yaitu hiperglikemia, diuresis osmotik, metabolisme asam lemak, dan asidosis metabolik. Pada penelitian ini kadar kalium didominasi pada kondisi normokalemia pada kedua kelompok. Hasil penelitian ini sejalan dengan penelitian yang dilakukan oleh Cieluch et al (2018) yang melaporkan bahwa rata-rata kadar kalium saat admisi pada kelompok yang patuh dengan penggantian kalium dan yang tidak patuh berada pada kondisi kadar kalium normokalemia yaitu 4,35 $\mathrm{mEq} / \mathrm{L}$ dan 4,22 mEq/L. Kadar kalium pasien saat admisi merupakan parameter pemberian terapi kalium pada pasien dengan KAD. Pemberian kalium pada pasien KAD dengan hiperkalemia perlu dilakukan penundaan terlebih dahulu hingga dilaksanakan pemeriksaan lanjutan. Apabila pada pemeriksaan lanjutan serum kalium telah menunjukkan kadar $<5,5 \mathrm{mEq} / \mathrm{L}$ dengan volume urin yang cukup, maka terapi kalium dapat diberikan. Hal ini dilakukan untuk mencegah terjadinya kondisi hipokalemia karena pasien menerima terapi insulin selama perawatan KAD (Dhatariya et al., 2013). 
134 | Oktaviani, R., dkk. / Jurnal Ilmiah Farmasi (Scientific Journal of Pharmacy) 17(2) Agustus-Desember 2021, 127-137

Penelitian ini menunjukkan adanya hubungan positif antara pemberian kalium dan resolusi ketoasidosis diabetik. Pemberian kalium dapat mempercepat terjadinya resolusi ketoasidosis diabetik selama waktu $\leq 24$ jam. Pada kelompok dengan pemberian kalium, sebanyak 16 pasien mencapai resolusi, sementara pada kelompok tanpa pemberian kalium hanya 4 pasien yang mencapai resolusi dalam kurun waktu $\leq 24$ jam. Pasien KAD dengan pemberian terapi kalium 2,667 kali lebih berpeluang mengalami resolusi $\leq 24$ jam dari awal terapi dimulai dibandingkan kelompok pasien tanpa pemberian kalium. Hasil penelitian ini didukung dengan penelitian yang dilakukan oleh Cielunch et al (2018) mengenai kepatuhan penggantian kalium berdasarkan protokol KAD. Parameter penilaian kepatuhan disesuaikan dengan protokol terapi ketoasidosis diabetik, antara lain dosis kalium terlalu tinggi, dosis kalium rendah, dan dosis kalium yang tidak diberikan. Kepatuhan penggantian kalium terhadap protokol mempengaruhi durasi perawatan ketoasidosis diabetik $(\mathrm{p}=$ 0,005). Kelompok pasien yang tidak patuh pada penggantian kalium terhadap protokol KAD (71\%) memiliki rata-rata waktu perawatan selama 37 jam, sementara kelompok yang patuh pada penggantian kalium terhadap protokol (29\%) memiliki rata-rata waktu perawatan selama 30 jam.

Parameter kadar kalium admisi menunjukkan perbedaan yang signifikan pada ke dua kelompok, sehingga dilakukan pemaparan terkait resolusi KAD berdasarkan kadar kalium admisi. Kelompok dengan pemberian kalium yang mencapai resolusi KAD $\leq 24$ jam berdasarkan kadar kalium admisi, yaitu kadar kalium hipokalemia sebesar 31,25\%, kadar kalium normokalemia sebesar 62,5\%, dan kadar kalium hiperkalemia sebesar 6,25\%. Kelompok tanpa pemberian kalium yang mencapai resolusi KAD $\leq 24$ jam berdasarkan kadar kalium admisi, yaitu kadar kalium normokalemia sebesar 50\% dan kadar kalium hiperkalemia sebesar 50\%. Hasil penelitian ini didukung oleh Lee et al (2018) yang menyatakan bahwa kadar kalium hiperkalemia pada saat admisi merupakan faktor yang menyebabkan resolusi ketoasidosis diabetik sulit untuk dicapai. Selain itu, penelitian yang dilakukan oleh Murthy et al (2005), melaporkan bahwa ketoasidosis diabetik dengan hipokalemia berat membutuhkan waktu selama 5 hari untuk mengatasi hipokalemia dan berdampak pada waktu pencapaian resolusi KAD yang lebih lama.

Berdasarkan analisis multivariat, diketahui terdapat pengaruh derajat keparahan terhadap pencapaian resolusi ketoasidosis diabetik. Derajat keparahan dikelompokkan menjadi dua, yakni derajat ringan-sedang dan derajat berat. Derajat keparahan ketoasidosis diabetik dinilai berdasarkan nilai pH darah, serum bikarbonat, anion gap, dan status mental (Kitabchi et al., 2009). Derajat keparahan berat menyebabkan beberapa pasien dalam keadaan koma, sehingga pencapaian resolusi KAD lebih lama jika dibandingkan dengan derajat keparahan ringan atau sedang dengan status 
135 | Oktaviani, R., dkk. / Jurnal Ilmiah Farmasi (Scientific Journal of Pharmacy) 17(2) Agustus-Desember 2021, 127-137

mental sadar atau drowsy. Hasil tersebut didukung oleh penelitian Cielunch et al (2018), bahwa derajat keparahan berpengaruh terhadap durasi perawatan ketoasidosis diabetik $(p=0,0001)$.

Riwayat diabetes melitus pada pasien ketoasidosis diabetik juga memiliki hubungan positif terhadap resolusi $(p=0,017)$. Hasil ini didukung oleh penelitian Newton and Raskin (2004) mengenai ketoasidosis diabetik pada DM tipe 1 dan DM tipe 2. Pasien KAD yang baru terdiagnosis diabetes melitus tipe 1 atau 2, membutuhkan waktu yang lebih lama sekitar 39,8 $\pm 13,3$ jam (p = 0,01) dan 36,0 $\pm 11,6(\mathrm{p}=0,04)$ untuk mencapai nilai urin keton negatif. Sedangkan pada pasien dengan riwayat diabetes melitus membutuhkan waktu yang lebih singkat yakni selama 28,9 $\pm 8,9$ jam untuk mencapai nilai urin keton negatif. Meskipun demikian, penelitian yang dilakukan oleh Balmier et al (2019) menunjukkan hasil yang berbeda, studi penatalaksanaan awal terapi ketoasidosis diabetik dengan jenis studi observasional multisenter ini menyatakan bahwa waktu resolusi KAD yang dicapai pada pasien dengan riwayat DM tipe 1 adalah selama 16 jam, pasien dengan riwayat DM tipe 2 adalah selama 14 jam, dan pasien KAD yang baru didiagnosis DM adalah selama 14 jam. Hasil penelitian ini menggambarkan bahwa tidak terdapat perbedaan yang bermakna pada waktu yang dibutuhkan dalam pencapaian resolusi KAD antara pasien KAD dengan riwayat diabetes melitus dan pasien yang baru terdiagnosis.

Berdasarkan penelitian Newton and Raskin (2004) serta Balmier et al (2019) terdapat perbedaan waktu yang dibutuhkan untuk mencapai resolusi ketoasidosis diabetik pada pasien dengan riwayat diabetes melitus dan pasien yang baru didiagnosis diabetes melitus, hal ini kemungkinan disebabkan oleh perbedaan penilaian resolusi ketoasidosis diabetik. Newton and Raskin (2014) menilai resolusi ketoasidosis diabetik berdasarkan status metabolik, keton urin negatif dan kemampuan makan pasien dengan normal. Sementara Balmier et al (2019), menilai resolusi ketoasidosis diabetik berdasarkan pada nilai keton darah $<0,5 \mathrm{mmol} / \mathrm{l}$ atau keton urin negatif atau waktu keluar dari ruang perawatan ICU (Intensive Care Unit).

\section{Kesimpulan}

Pemberian kalium memiliki hubungan terhadap resolusi KAD dalam waktu $\leq 24$ jam dari awal terapi KAD dimulai. Sebesar 48,5\% pasien dengan pemberian kalium mengalami resolusi KAD dalam waktu $\leq 24$ jam. Faktor lain yang mempengaruhi ketercapaian resolusi ketoasidosis diabetik di antaranya adalah derajat keparahan dan riwayat diabetes melitus. 


\section{Daftar pustaka}

Alledregde, B. K., Corelli, R. L., Ernest, M. E., Guglielmo, J. B., Jacobson, P. A., Kradjan, W. A., \& Williams, B. R. (2013). Koda-Kimble \& Young's Applied Therapeutics. The Clinical Use Of Drugs. Diabetes mellitus, dalam Craig Williams, L.A.K. (10). United States of America: Lippincott Williams \& Wilkins.

Balmier, A., Dib, F., Serret-Larmande, A., De Montmollin, E., Pouyet, V., Sztrymf, B., Megarbane, B., Thiagarajah, A., Dreyfuss, D., Ricard, J. D., \& Roux, D. (2019). Initial Management of Diabetic Ketoacidosis and Prognosis According to Diabetes Type: a French Multicentre Observational Retrospective Study. Ann Intensive Care, 9(1), 91. doi:10.1186/s13613-019-0567-y

Cieluch, A., Uruska, A., Falkowski, B., Błońska, M., Niedźwiecki, P., Balawajder, K., Araszkiewicz, A., \& Zozulińska-Ziółkiewicz, D. (2018). Nonadherence to Potassium Replacement Protocol Leads to Prolonged Management of Diabetic Ketoacidosis. Pol Arch Intern Med, 128(7-8), 416-420. doi:10.20452/pamw.4293

Dhatariya, K., Savage, M., \& Kelly, T. (2013). Joint British Diabetes Societies Inpatient Care Group. The Management of Diabetic Ketoacidosis in Adults (2 ed.). UK The intensive Care Society.

Kitabchi, A. E., Umpierrez, G. E., Miles, J. M., \& Fisher, J. N. (2009). Hyperglycemic Crises in Adult Patients with Diabetes. Diabetes Care, 32(7), 1335-1343. doi:10.2337/dc09-9032

Lee, M. H., Calder, G. L., Santamaria, J. D., \& MacIsaac, R. J. (2018). Diabetic Ketoacidosis in Adult Patients: an Audit of Factors Influencing Time to Normalisation of Metabolic Parameters. Intern Med J, 48(5), 529-534. doi:10.1111/imj.13735

Murthy, K., Harrington, J. T., \& Siegel, R. D. (2005). Profound Hypokalemia in Diabetic Ketoacidosis: a Therapeutic Challenge. Endocr Pract, 11(5), 331-334. doi:10.4158/ep.11.5.331

Newton, C. A., \& Raskin, P. (2004). Diabetic Ketoacidosis in Type 1 and Type 2 Diabetes Mellitus: Clinical and Biochemical Differences. Arch Intern Med, 164(17), 1925-1931. doi:10.1001/archinte.164.17.1925

Nyenwe, E. A., \& Kitabchi, A. E. (2016). The Evolution of Diabetic Ketoacidosis: An Update of Its Etiology, Pathogenesis and Management. Metabolism, 65(4), 507-521. doi:10.1016/j.metabol.2015.12.007

Parsons, P. E., Kronish, J. P., Stapleton, R. D., \& Berra, L. (2019). Critical Care. Journal of Chemical Information and Modeling, 53(9), 1689-1699.

Westerberg, D. P. (2013). Diabetic Ketoacidosis: Evaluation and Treatment. American Family Physician, 87 (5), 337-346. 